\title{
LAMBATNYA PENANGANAN PERKARA TINDAK PIDANA KARENA TIDAK OPTIMALNYA KOORDINASI DALAM TAHAP PRAPENUNTUTAN (URGENSI PERWUJUDAN SISTEM JAKSA ZONA)
}

\author{
Nurul Dewinta ${ }^{1}$, Haeranah$^{2}$, Nur Azisa ${ }^{3}$
}

\begin{abstract}
This study purpose to determine: the implementation of coordination between investigators and public prosecutors at the pre-prosecution stage, obstacles that arise in the implementation of coordination between investigators and public prosecutors as well as efforts made to maximize the coordination function at the pre-prosecution This research is empirical normative research. In order to obtain data relevant to the needs of this research, the author conducted a study at the Kotamobagu District Prosecutor's Office and Kotamobagu Resort Police. The results of the study show that (1) In handling a criminal case, the party responsible for law enforcement should establish a good coordination so that the duration of the case handling process does not occur which results in a fast, simple and low cost judicial principle. However, the coordination carried out by investigators at the Kotamobagu Resort Police and the public prosecutor at the Kotamobagu District Attorney's Office at the pre-prosecution stage has not been carried out to the maximum. (2) Constraints that arise in coordinating and the efforts made to maximize the coordination function at the pre-prosecution stage based on the Kotamobagu District Prosecutor's case study and Kotamobagu Resort Police. 3) the community uses the law as a tool to achieve personal goals, for example, get material benefits so that the efforts taken are to carry out legal counseling to the community.
\end{abstract}

Kata kunci: Koordinasi, Penuntut Umum, Penyidik, Prapenuntutan.

\section{PENDAHULUAN}

Prapenuntutan merupakan tugas awal penuntut umum dalam menangani perkara tindak pidana. Prapenuntutan ialah salah satu tugas dan kewenangan yang sangat penting yang dimiliki oleh Kejaksaan. Penuntut umum setelah menerima SPDP dari penyidik, penuntut umum mengikuti perkembangan penyidikan yang dilakukan oleh penyidik, kemudian setelah berkas perkara diterima oleh penuntut umum, penuntut umum segera meneliti apakah hasil penyidikan itu sudah lengkap atau belum. Dalam hal hasil penyidikan belum lengkap, penuntut umum mengembalikan berkas perkara tindak pidana kepada penyidik disertai petunjuk tentang hal yang harus dilengkapi. Tindak pidana (delict) atau yang disebut juga peristiwa pidana ialah suatu perbuatan atau rangkaian perbuatan yang dapat dikenakan hukuman pidana. Suatu peristiwa hukum dapat dinyatakan

\footnotetext{
${ }^{1}$ Mahasiswa Program Magister Hukum, Fakultas Hukum, Universitas Hasanuddin

${ }^{2}$ Bagian Hukum Pidana, Fakultas Hukum, Universitas Hasanuddin

${ }^{3}$ Bagian Hukum Pidana, Fakultas Hukum, Universitas Hasanuddin
} 
sebagai peristiwa pidana kalau memenuhi unsur - unsur pidananya. ${ }^{4}$

Kelengkapan berkas perkara terdiri dari :

- Kelengkapan formil, meliputi kelengkapan administrasi berkas perkara, dan

- Kelengkapan materil meliputi kelengkapan unsur tindak pidana dan fakta perbuatan, 6 kejadian atau hal dari masing-masing unsur delik, serta alat bukti yang mendukung setiap fakta.

Suatu hasil penyidikan dikatakan lengkap apabila telah diperoleh sekurangkurangnya dua alat bukti sah menurut undangundang. Berhasil tidaknya penuntutan banyak tergantung pada kecermatan dan ketelitian penuntut umum dalam meneliti berkas perkara. $^{5}$

Namun demikian, di dalam praktek sering terjadi penyidik yang mengirimkan SPDP sudah disertai dengan Berkas Perkara. Sehingga, timbul berbagai macam pemasalahan dalam penanganan perkara itu sendiri. Seperti misalnya, penerapan Pasal yang tidak tepat maupun tindakan-tindakan penyidikan yang tidak sesuai dengan KUHAP. Sehingga, hal tersebut mengakibatkan ketidaklengkapan berkas perkara suatu perkara pidana yang diajukan oleh penyidik kepada Kejaksaan. Ketidaklengkapan tersebut berimbas kepada lamanya penanganan perkara tindak pidana itu sendiri. Apalagi, didalam KUHAP tidak terdapat pasal yang mengatur batas waktu penanganan perkara tindak pidana pada tingkat penyidikan atau berapa kali batas bolak baliknya berkas perkara hasil penyidikan antara pihak penyidik dan penuntut umum.

Dalam sistem peradilan pidana, polisi dan jaksa merupakan dua institusi penegak hukum yang memiliki hubungan fungsional

\footnotetext{
4 Abdullah Marlang, Irwansyah, dan Kaisaruddin, Pengantar Hukum Indonesia, Cet.2. Makassar:ASPublishing,2011. Hal.67

5 Adnan Paslyadja, Hukum Pembuktian (Penekanan pada Hukum Acara Pidana). (Jakarta : Pusat Diklat Kejaksaan RI , 1997), hlm. 3
}

sangat erat dalam menangani perkara tindak pidana. Kedua institusi ini seharusnya dapat bekerja sama dan berkoordinasi dengan baik untuk mencapai tujuan dan sistem ini, yaitu menanggulangi kejahatan atau mengendalikan terjadinya kejahatan agar berada dalam batasbatas toleransi yang dapat diterima masyarakat.

Agar dalam pelaksanaan pembangunan, termasuk pembangunan hukum, asas rasional, efisien, serta efektivitas tidak dapat diabaikan dan kesadaran akan kesulitan/kerumitan untuk memperoleh kebenaran materiil hendaknya mendorong kerja sama serta saling melengkapi antara sesama aparat penegak hukum. $^{7}$

\section{METODE}

Penelitian ini merupakan penelitian normatif empiris. Dalam rangka memperoleh data yang relevan dengan kebutuhan penelitian ini, penulis melakukan penelitian di Kejaksaan Negeri Kotamobagu dan Kepolisian Resor Kotamobagu. Penulis memilih lokasi penelitian tersebut karena terdapat cukup data yang relevan terkait Pelaksanaan Koordinasi antara Penyidik Polri dan Jaksa Penuntut Umum dalam Prapenuntutan. Selain itu, penulis bekerja selaku Calon Jaksa pada kantor Kejaksaan Negeri Kotamobagu yang setiap harinya berhubungan baik secara langsung maupun tidak langsung dengan Penyidik pada Kepolisian Resor Kotamobagu dan Penuntut Umum pada Kejaksaan Negeri Kotamobagu.

\section{HASIL DAN PEMBAHASAN}

\section{Pelaksanaan Koordinasi Antara Penyidik dan Penuntut Umum pada Tahap Prapenuntutan}

Kesempurnaan dalam penyidikan akan menghasilkan keberhasilan dalam penuntutan, oleh karena itu tidak dapat

\footnotetext{
${ }^{6}$ Amir llyas, Asas - Asas Hukum Pidana, Yogyakarta:

Rangkang education \& Pukab,2012, hlm.28

${ }^{7}$ Loc.Cit
} 
dihindari bahwa ada hubungan kerja sama serta hubungan yang saling mengawasi antara polisi sebagai penyidik dan jaksa sebagai penuntut umum. Koordinasi awal antara penyidik dan penuntut umum dimulai pada saat diterbitkannya Surat Pemberitahuan Dimulainya Penyidikan (SPDP) dan mengirimkannya ke Kejaksaan. Sebagaimana diatur dalam putusan MK Nomor 130/PUUXIII/2015 tanggal 11 Januari 2017, bahwa Penyidik wajib mengirimkan SPDP ke kejaksaan, terlapor, dan pelapor. Kemudian, Kejaksaan setelah menerima SPDP tersebut segera menunjuk Penuntut Umum yang akan mengikuti perkembangan penyidikan yang dilakukan oleh penyidik. Penuntut Umum yang menangani perkara tersebut, melakukan pemantauan terhadap perkembangan penyidikan perkara yang ditangani dengan cara menghubungi Penyidik yang bersangkutan dan wajib untuk menanyakan terkait kasus posisi maupun perkembangan penyidikan sementara yang telah dilakukan oleh Penyidik. Penuntut Umum juga diberikan kewenangan untuk meneliti penghentian Penyidikan yang dilakukan oleh Penyidik.

Setelah melakukan penyidikan, penyidik menuangkan seluruh hasil penyidikan kedalam satu berkas perkara yang kemudian dikirimkan ke kejaksaan atau penuntut umum yang menangani perkara tersebut. Lalu setelah penuntut umum menerima berkas perkara dari penyidik; penuntut umum akan meneliti kelengkapan berkas perkara dengan membuatkan checklist dan Berita Acara Pendapat. Dalam waktt tujuh hari, penuntut umum harus memberitahukan kepada penyidik apakah hasil penyidikan itu sudah lengkap atau belum sesuai apa yang diatur dalam Pasal 138 (1) KUHAP. Jika hasil penyidikan belum lengkap, setelah memberitahukan kepada penyidik bahwa hasil penyidikan belum lengkap, dalam waktu 7 hari kemudian, penuntut umum akan mengirimkan petunjuk tentang hal yang harus dilakukan penyidik untuk melengkapi berkas perkara tersebut. Kemudian dalam waktu 14 hari sejak tanggal penerimaan berkas perkara, penyidik harus sudah menyampaikan kembali berkas perkara itu kepada Penuntut Umum (Pasal 138 Ayat (2)). Yang perlu diteliti oleh penuntut umum atas berkas perkara yang diserahkan oleh penyidik ialah kelengkapan berkas, berupa kelengkapan formil dan kelengkapan materil. Kelengkapan formil berarti kelengkapan administrasi teknis justisial yang terdapat pada setiap berkas perkara sesuai dengan keharusan yang harus dipenuhi oleh ketentuan hukum yang diatur dalam Pasal 121 dan Pasal 75 KUHAP, termasuk semua ketentuan kebijaksanaan yang telah disepakati oleh instansi penegak hukum dan yang telah melembaga dalam praktek penegakan hukum, yang mana kelengkapan formal itu meliputi segala sesuatu yang berhubungan dengan formalitas/persyaratan, tata cara penyidikan yang harus dilengkapi dengan Surat Perintah, Berita Acara, Izin/Persetujuan Ketua Pengadilan. di samping penelitian kuantitas kelengkapan syarat formal, perlu diteliti pula segi kualitas kelengkapan tersebut, yakni keabsahannya sesuai dengan ketentuan undang-undang. Kelengkapan materil ialah kelengkapan informasi, data, fakta dan alat bukti yang diperlukan bagi kepentingan pembuktian. Kreteria yang dapat digunakan sebagai tolak ukur kelengkapan materil antara lain:

Apa yang terjadi (tindak pidana beserta kualifikasi dan Pasal yang dilanggar;

Siapa pelaku, siapa-siapa yang melihat, mendengar, mengalami peristiwa tersebut (tersangka, saksi-saksi / ahli);

Bagaimana perbuatan itu dilakukan (moodus operandi);

Dimana perbuatan dilakukan (locus delicti);

Bilamana perbuatan dilakukan (tempus delicti);

Akibat apa yang ditimbulkan (ditinjau secara victimologi);

Apa yang hendak di capai dengan perbuatan tersebut (motivasi yang mendoronng pelaku).

Kelengkapan materil terpenuhi bila segala sesuatu yang diperlukan bagi kepentingan pembuktian telah tersedia sebagai hasil penyidikan, apabila penuntut umum berpendapat hasil pemeriksaan 
penyidik terhadap terdakwa, saksi atau yang lain, masih perlu dilengkapi dengan penyidikan tambahan dalam rangka penyempurnaan untuk membuktikan di muka sidang pengadilan, penuntut umum wajib memberi petunjuk apa yang perlu dilakukan penyidik. Ketika penyidik telah selesai melakukan pemeriksaan tambahan dan melengkapi berkas perkara, penyidik kemudian mengirimkan kembali berkas perkara tersebut kepada Penuntut Umum untuk diteliti kembali apakah petunjuk Penuntut Umum yang diberikan sebelumnya kepada Penyidik telah dilengkapi atau belum. Apabila Penuntut Umum mengambil sikap bahwa hasil penyidikan sudah lengkap, maka Penuntut Umum membuat surat pemberitahuan bahwa hasil penyidikan telah lengkap (P-21) dan mengirimkannya kepada Penyidik kemudian melakukan koordinasi dengan Penyidik terkait Penyidik dapat segera menyerahkan Tersangka dan Barang Bukti kepada Kejaksaan guna menentukan apakah perkara tersebut layak atau tidak untuk dilimpahkan ke Pengadilan. Melimpahkan tersangka dan barang bukti (Tahap II) ini bisa dilakukan kapan saja setelah Penuntut Umum menyerahkan Surat Pemberitahuan bahwa Hasil Penyidikan Sudah Lengkap (P-21), tergantung pembicaraan dan kesepakatan antara Penyidik dengan Penuntut Umum.

\section{Hambatan dan Upaya dalam memaksimalkan fungsi koordinasi pada tahap prapenuntutan}

Berdasarkan substansi hukumnya : hambatan yang timbul dalam pelaksanaan koordinasi pada tahap prapenuntutan ialah Pengiriman Surat Pemberitahuan Dimulainya Penyidikan (SPDP) yang harusnya paling lambat waktu 7 (tujuh) hari telah harus dikirimkan ke sesuai dengan putusan MK Nomor 130/PUU-XIII/2015 tanggal 11 Januari 2017, namun masih banyak penyidik yang mengirimkannya lebih dari 7 (tujuh) ke kejaksaan, terlapor, dan pelapor. Bahkan, beberapa ditemukan SPDP diterima oleh Kejaksaan sudah bersamaan dengan berkas perkara (Tahap I) dan masih ditemukan dalam beberapa perkara, penyidik tidak mengirimkan tembusan Surat Pemberitahuan Dimulainya Penyidikan (SPDP) kepada pihak terlapor dan korban. Padahal, hal tersebut dapat membuat perkara itu batal demi hukum. Selain itu, pada saat penyidikan dilakukan, kurangnya kesadaran dari Penyidik maupun Penuntut Umum terkait konsep Criminal Justice System. Sehingga, Penyidik tidak bertindak secara aktif untuk menghubungi Penuntut Umum dan begitupun sebaliknya. Sehingga, banyak Penyidik mengirimkan berkas perkara ke Kejaksaan tanpa adanya koordinasi setelah pengiriman Surat Pemberitahuan Dimulainya Penyidikan (SPDP). Dikarenakan koordinasi yang tidak dilakukan sejak awal, pada berkas perkara yang diterima oleh Kejaksaan Negeri Kotamobagu, setelah penuntut umum melakukan penelitian, banyak menemukan kekurangan seperti ditemukan pasal yang disangkakan tidak sesuai dengan posisi kasus dari hasil penyidikan penyidik atau bahkan bisa saja Penuntut Umum berpendapat bahwa itu bukan merupakan Tindak Pidana. Juga seringnya terjadi bolak balik berkas perkara, ketika Penyidik berpandangan bahwa Berkas Perkara telah lengkap dan Penyidik telah melakukan Penyidikan secara maksimal. Namun, Penuntut Umum berpendapat bahwa hasil Penyidikan tersebut belum maksimal dan Berkas Perkara belum lengkap. Sehingga, Penuntut Umum menentukan sikap untuk mengembalikan berkas perkara disertai dengan petunjuk. Setelah itu, Penyidik kembali mengirimkan berkas perkara tanpa memenuhi petunjuk. Sehingga, Penuntut Umum mengembalikan Berkas Perkara disertai dengan petunjuk untuk yang kedua kalinya dan seterusnya. Hal tersebut terjadi dalam beberapa kasus di Kantor Kejaksaan Negeri Kotamobagu dikarenakan perbedaan pandangan antara Penyidik dengan Jaksa. Hal tersebut menyebabkan ketidakpastian hukum bagi pihak pelapor maupun terlapor, karena KUHAP tidak mengatur mengenai berapa kali Berkas Perkara tersebut dapat dikembalikan oleh Penuntut Umum kepada Pihak Penyidik.

Pada saat hasil penyidikan dinyatakan telah lengkap oleh Penuntut Umum, biasanya 
terjadi kendala yaitu pelimpahan tersangka dan barang bukti ke Kejaksaan (Tahap II) yang tak kunjung dilakukan karena tersangka yang tidak ditahan pada tahap penyidikan atau dilakukan penahanan rumah/kota oleh Penyidik, tidak hadir memenuhi panggilan penyidik. Sehingga, waktu pelimpahan menjadi terlambat. Upaya yang dilakukan untuk memaksimalkan fungsi koordinasi antara penyidik dan penuntut umum pada tahap prapenuntutan, yaitu Rancangan Undang-Undang Kitab Hukum Acara Pidana (RUU-KUHAP) yang didalamnya terdapat aturan tentang Jaksa Zona.

Berdasarkan struktur hukumnya : Masih lemahnya pengetahuan, pemahaman agama, dan ekonomi aparat penegak hukum, serta proses rekruitmen yang tidak transpara. Sehingga dapat dipertegas bahwa faktor penegak hukum memainkan peran penting dalam memfungsikan hukum. Kalau peraturan sudah baik, tetapi kualitas penegak hukum rendah maka akan ada masalah. Demikian juga, apabila peraturannya buruk sedangkan kualitas penegak hukum baik, kemungkinan munculnya masalah masih terbuka. Upaya yang dilakukan untuk memaksimalkan fungsi koordinasi antara penyidik dan penuntut umum pada tahap prapenuntutan dalam struktur hukum adalah Penambahan SDM, Peningkatan kualitas, serta kesadaran tugas pokok fungsi, dan kewenangan masing-masing aparat sebagaimana yang telah diatur dalam KUHAP. Selain itu, perlu juga diingatkan kembali terhadap masing-masing pihak terkait Intergrated Criminal Justice System, yang pada pokoknya menekankan bahwa dalam penanganan perkara pidana antara Penyidik dengan Penuntut Umum adalah suatu kesatuan yang tidak dapat dipisahkan untuk mencapai suatu tujuan yakni menegakkan hukum.

Berdasarkan Kultur hukumnya : hambatan yang timbul adalah sering terdapat masyarakat dalam hal ini pelapor hanya menggunakan hukum sebagai alat untuk mencapai tujuan pribadi misalnya mendapatkan keuntungan secara materil. Menurut Achmad Ali jika suatu aturan hukum dapat ditaati oleh sebagian besar target yang menjadi sasaran ketaatannya, maka dapat diartikan bahwa aturan hukum tersebut efektif. ${ }^{8}$ Pada prakteknya, sering ditemukan Penyidik menyampaikan pada terkendala dalam memenuhi petunjuk dari Penuntut Umum untuk melakukan pemeriksaan tambahan dikarenakan saksi sudah tidak berkenan untuk hadir dengan alasan bahwa telah terjadi perdamaian antara saksi dengan tersangka. Sehingga, kendala yang terjadi tersebut kemudian menyebabkan penyidik telah melewati batas waktu yang ditentukan oleh KUHAP untuk melakukan pemeriksaan tambahan sebagaimana diatur dalam Pasal 138 ayat (2) KUHAP.

Sehingga, secara administrasi Penuntut Umum wajib untuk memberitahukan bahwa waktu pemeriksaan tambahan tersebut telah habis yakni selama 14 (empat belas) hari dan Jaksa wajib untuk mengembalikan SPDP (Surat Pemberitahuan Dimulainya Penyidikan) perkara tersebut kepada Penyidik. Setelah ditelusuri lebih lanjut oleh Penyidik didapatkan fakta bahwa ternyata tersangka telah memberikan sejumlah uang kepada saksi yang menjadi korban untuk mengganti biaya pengobatan dan lain-lain. Sehingga, saksi merasa tidak perlu lagi untuk menghadiri panggilan dari pihak Kepolisian karena sudah mendapatkan sejumlah uang dari pihak Tersangka.

Upaya Upaya dalam kurangnya kesadaran hukum masyarakat dilakukanlah berbagai upaya oleh lembaga Kejaksaan. Seperti misalnya salah satu upaya yang dilakukan dalam meningkatkan kesadaran masyarakat akan hukum adalah dengan melakukan penyuluhan dan penerangan hukum "Jaksa Masuk Sekolah", Penyuluhan hukum

${ }^{8}$ Achmad Ali, Menguak Teori Hukum Dan Teori Peradilan Vol I. Jakarta, Kencana: 2012 hlm. 14 
dilakukan oleh Kejaksaan Negeri

Kotamobagu tidak hanya terhadap anak-anak

Sekolah saja. Melainkan terhadap masyarakat umum di setiap Kecamatan di wilayah hukum Kejaksaan Negeri Kotamobagu. Biasanya masyarakat dikumpulkan di Kantor Kecamatan. Lalu, tim dari Kejaksaan Negeri Kotamobagu memberikan pemaparan dan membuka sesi Tanya jawab secara interaktif dengan masyarakat umum. Selain itu, Kejaksaan Negeri Kotamobagu juga secara rutin mengadakan kegiatan Penyuluhan dengan program "Jaksa Menyapa". Yaitu suatu program kerja sama antara Kejaksaan dengan Radio Republik Indonesia (RRI) untuk memberikan kesempatan kepada Masyrakat Pendengar Radio agar dapat berinteraksi secara langsung dengan JaksaJaksa di Wilayah Hukumnya masing-masing lewat media interaktif.

\section{PENUTUP}

Dalam menangani suatu perkara tindak pidana, pihak yang bertanggungjawab dalam penegakan hukum seharusnya menjalin suatu koordinasi yang baik agar tidak terjadi masalah dikemudian hari, seperti lamanya waktu proses penanganan perkara yang mengakibatkan asas peradilan cepat, sederhana dan biaya ringan tidak terwujudkan. Namun, pelaksanaan koordinasi yang dilakukan oleh penyidik di Kepolisian Resor Kotamobagu dan Penuntut Umum di Kejaksaan Negeri Kotamobagu pada tahap prapenuntutan belum terlaksana dengan maksimal. Hal ini dikarenakan antara penyidik dan penuntut umum sejak awal tidak melakukan koordinasi dengan baik, sehingga pada setiap tahapan dalam proses prapenuntutan masih berjalan dengan lamban, apalagi KUHAP yang dijadikan pedoman belum mengatur tentang lamanya waktu penyidikan atau waktu prapenuntutan ataupun batas waktu bolak baliknya berkas perkara pada saat prapenuntutan, sehingga mengakibatkan lamanya proses penanganan perkara tindak pidana.

Solusi dari lambannya penanganan perkara yang diakibatkan bolak-baliknya berkas perkara dari kejaksaan dan kepolisian adalah suatu sistem hukum acara yang dikenal didalam RUU KUHAP dengan istilah Jaksa Zona. Jaksa zona adalah Jaksa yang bekerja sesuai dengan unit wilayah kepolisian yang berwenang menyidik. Dengan adanya jaksa zona, penuntut umum dan penyidik akan duduk bersama sejak dimulainya penyidikan. Penyidik dan Penuntut Umum akan bekerja sama hingga berkas perkara dinyatakan siap ke pengadilan. Kerjasama dapat dilakukan oleh penyidik dan penuntut umum sejak dikeluarkannya Surat Pemberitahuan Dimulainya Penyidikan (SPDP). Sehingga, diharapkan tidak akan pernah terjadi lagi yang dinamakan bolak balik berkas perkara antara penyidik dengan penuntut umum.

$-000-$

\section{DAFTAR PUSTAKA}

Abdullah Marlang, Irwansyah, dan Kaisaruddin. (2011). Pengantar Hukum Indonesia. Aspublishing. Makassar.

Achmad Ali. (2012). Menguak Teori Hukum Dan Teori Peradilan Vol I. Kencana, Jakarta.

Adnan Paslyadja. (1997). Hukum Pembuktian (Penekanan pada Hukum Acara Pidana). Pusat Diklat Kejaksaan RI. Jakarta.

Amir Ilyas. (2012). Asas-Asas Hukum Pidana. Rangkang Education \& Pukab. Yogyakarta. 